\title{
Exploration on the subject construction of commercial university under the background of "double top class"
}

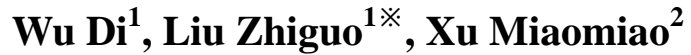 \\ ${ }^{1}$ High education research and teaching quality assessment center, Harbin University of Commerce, Harbin, \\ 150028, China \\ ${ }^{2}$ Law school, Harbin University of Commerce, Harbin, 150028, China
}

Keywords: "Double first class"; common local universities; business; discipline construction Abstract: For ordinary local universities, the construction of "double first class" is both an opportunity and a lot of challenges. Seize the opportunity, face up to the challenge, take the road of characteristic development, let go of thinking to seek a variety of ways, it is the role of common local universities in the construction of "double first class". Commercial universities to grasp the future of China's economic lifeline, in the "double class" construction has an integral value. Ordinary local business universities should take this as an opportunity to deepen the reform of discipline construction, service regional economic development. Learn from international experience, the construction ideas of ordinary local business universities first-class discipline, can obtain first-class academic achievements from the formation of first-class academic echelon, and solve the new problems in economic development, cultivate the first-class enterprise management to begin.

\section{“双一流”背景下地方普通商科高校学科建设探索}

\author{
吴迪 $^{1}$, 刘志国 ${ }^{1}$, 徐苗苗 ${ }^{2}$ \\ 1.哈尔滨商业大学高教研究与教学质量评估中心, 黑龙江 哈尔滨 150028 \\ 2.哈尔滨商业大学法学院，黑龙江 哈尔滨 150028
}

关键词: “双一流”; 普通地方高校; 商科; 学科建设

摘 要：对地方普通高校而言“双一流”建设既是发展机遇, 又面临诸多挑战。抓住机遇、正 视挑战, 走特色发展之路, 放开思维寻求多种途径, 是普通地方高校在“双一流”建设中的角 色定位。商科院校掌握中国未来经济命脉，在“双一流”建设中具有不可或缺的价值。普通地 方商科高校要以此为契机, 深化学科建设改革, 服务区域经济发展。吸取国际经验, 普通地 方商科高校一流学科的建设思路, 可以从组建一流学术梯队、获得一流学术成果, 解决经济 发展中的新问题、培养一流企业经营管理者来着手。

\section{1. 引 言}

2015 年 10 月 24 日，国务院颁布《统筹推进世界一流大学和一流学科建设总体方案》（以 下简称《方案》），标志着我国开始从高等教育大国向高等教育强国迈进。《方案》是为了 克服以往“985”、“211” 工程等重点建设身份固化、竞争缺失、重复交叉等问题，使我国高等 教育再次焕发活力，向高等教育强国迈进而制定。对普通地方高校而言“双一流”建设既是发 展机遇，又面临诸多挑战。在国家总体规划下，普通地方高校要结合各自实际情况推进。

\section{2. “双一流”建设带来的机遇与挑战}

首先，地方普通高校有了重新一战、跻身强校之林的机会。此外，对于“双一流”建设成绩 
表现突出的地方高校，中央财政会通过支持地方高校发展的相关资金给予引导支持。第三， 地方高校在 “双一流”建设中有多种路径选择，综合实力较强的高校可将目标定位于建设一流 大学, 个别学科较强的可着重建设一流学科, 或根据实际情况两手抓、相互扶持和促进。挑 战与机遇并存, 普通地方高校将迎面遇到如下问题：在与传统强校相比之下，如何吸引高层 次人才, 让人才愿意来、留得住; 如何使得所培养学生在社会需求方面具有独特优势; 如何 利用有限的资源和平台取得一流学术成果。

在所有困难背后, 还一定程度上存在一个原动力的缺失, 即对科研与教学真正的热爱, 而 不是迫于评职称的压力。写论文、做科研不是因为需要一定论文数量, 而是对学术本身的向 往和热爱, 是对科学未解之谜的好奇。当多数人都成为这样, 学校自然而然会被学术自由的 㞣围包围。同理, 教学不是因为课时量的需要, 而是怀有育人成才的使命和热情。用心来教、 用爱来教, 就不愁不出拔尖创新的杰出人才。

许多教师认为没有时间和精力“十年磨一剑”, 尤其是中青年教师, 仍然普遍存在生活压力, 不快速求得职称晋升, 就难以改观。评价一位教师的能力不应只看论文和课题, 定量评价的 简单粗暴已经捆绑了教师的灵魂, 造成了杰出人才培养的疏漏。学术评价问题不得到缓解, “双 一流”建设就在学校内部存在阻碍, 很难脚踏实地、上下一心的建设“双一流”。首先, 应发挥 学术自治和社会多元化评价的作用, 改革现有教师评价体系。此外, 需要寻求群体价值观的 升华, 多些爱和奉献, 追求卓越, 成功自会不期而至。真、善、美的价值观, 无论在哪个时 代都是最可贵的品质，是人类永恒之追求。

\section{3. 普通地方高校在 “双一流”建设中的角色}

所有大学都实现“双一流”是天方夜谭，但“双一流”建设也绝不仅仅是传统“985、211”工程 院校的天赋使命。在一个新时代、新机遇面前, 普通地方高校不能望而却步, 在做之前就轻 易断定不可能, 而目光短浅的放弃了新生的机会。我国已明确提出 “双一流”建设在学校数量 上的总体目标，2020 年有“若干所”、2030 年有“更多的”、本世纪中叶“数量......进入世界前 列”, 可见国家需要数量众多的普通地方高校提升和晋升成为“双一流”院校, 国家定会努力扶 持有潜力、有诚意的普通地方高校的发展和崛起。同时, 也不能盲目乐观, 要正确评估自身 实力。普通地方高校没有传统“985”、“211”工程院校基础雄厚，必须走特色发展之路，放开 思维寻求多种途径。

在我国 2500 多所普通高校中，商科类院校占有重要席位，这是因为我国的基本国策是以 经济建设为中心, 而商科院校存在的意义就是要把经济建设搞上去, 它承担着为祖国培养高 层次企业经营管理者的重要使命，掌握中国未来的经济命脉。因而在“双一流”建设中，商科 高校必须积极探索。

《方案》在指导思想中明确指出以支撑创新驱动发展战略、服务经济社会发展为导向。在 服务经济社会发展, 特别是服务区域经济发展上, 地方商科院校有得天独厚之优势, 同时也 是发展家乡义不容辞的责任。在“双一流”背景下, 作为中国大学的重要组成部分, 普通地方 商科高校要以此为契机, 深化学科建设改革, 努力打造一流学科, 服务区域经济发展。

\section{4. 商科高校一流学科建设思路}

《方案》明确指出 “双一流”建设要以学科建设为基础。普通地方商科高校可能在综合实力 上较弱, 而以特色学科为突破口, 进行一流学科建设就是正确选择。国际上的一流学科通常 具有一流的学术队伍、一流的学术成果和一流的学生质量, 也就是具有该学科领域的领军人 
物和一群高层次人才; 在国际一流期刊发表原创性文章并具有较高引用率; 培养出大批杰出 人才。对普通地方商科院校而言，也要在这三方面着重建设，并注重发挥自身优势。

\section{1 组建一流学术梯队}

一流学术梯队表现为既有领军人物, 又有高水平学术团队, 普通地方高校往往是仅有其一, 甚至二者均缺失。如何有效引进高层次人才是永恒话题, 不仅要引入人才、留住人才, 更要 使人才获得发展。这首先需要资金、制度支持; 此外需要学校自身营造学术自由的环境, 形 成学术崇拜、讨论研究的风气; 还要共同完成课题研究, 打造学术团队, 逐渐形成凝聚力。

在人才引进和师资培养上, 商科高校对师资队伍有自己的要求。首先, 特别看重思想品德, 这是商科教师最重要、最核心的要求。因为这是专门和钱打交道的一批人，是职业研究怎么 赚钱的人，务必要政治立场坚定，时刻警醒什么是底线，有坚定的法制观念，坚决杜绝一切 向钱看，一味钻钱眼的错误做法。第二，在知识结构上特别注重理论和实践相结合。钱的问 题，往大说是关系国家经济运行，往小说和每个人的生活质量息息相关，每个人都是自己财 务的经营管理者, 每个知识点都具有较大的实践属性, 要求教师必须紧紧将理论和实践结合 起来, 才能成为一个合格的商科院校教师。第三，在基本能力要求上特别看重灵敏快速的分 析能力和灵活应变能力。商机往往转瞬即逝, 不可复归, 商科教师要有灵敏快速的分析能力, 帮助和培养学生敏锐的抓住商机的能力。此外, 在错综复杂的经济关系和人际关系中要能随 机应变, 方能谈成买卖。

上述品德和能力的养成, 即需要理论支撑, 又离不开商海实践中的千锤百炼。商科教师既 要提高学历又要注重行业、企业的实践经历。当下教师队伍现状是要么引进青年博士, 刚出 校门没有实践经验, 要么外聘在企业摸爬滚打多年的企业家, 又欠缺理论素养和教学经验。 短期通过外聘的方式可以弥补不足, 但是长远打算还应努力培养兼顾理论和实践能力的人才, 刚毕业的青年博士思维活跃、接受新知识能力强, 可以创造条件让他们多在企业实践中得到 历练和成长。商科类院校天然的在创业项目上有优势, 青年教师也可以借助大创项目, 和学 生团队们一起成长，在做项目的过程中实践自己的理论知识，增强实践能力。

\section{2 获得一流学术成果, 解决经济发展中的新问题}

原创性不够，始终是我国科研工作者面对的共性难题，原因或许就在于高校教师理论和实 践仍然存在鸿沟。在我国的经济发展和改革中, 现状是不断冒出新问题、产生新矛盾的, 商 科高校的科学研究, 要瞄准我国经济发展中这些不断涌现的新问题, 为经济的增速发展做出 实际贡献。现实问题得到解决, 在这个过程中, 就必然会获得许多理论和实践的创新, 从而 获得丰硕的一流科研成果。并且这些科研成果应获得国际同行认同。

从“以学生为中心”的角度讲, 科研成果能够在一定程度上丰富教学内容, 为学生提供最前 沿的知识; 从学科评估的角度讲, 高水平学术成果又是量化评价的重要指标。因而一流学科 必然伴随一流的学术成果, 而一流的学术成果必然要能够转化为生产力、转化为课程, 来为 国家、社会和学生服务。

商科类高校在集中力量培养学生经营管理能力的同时，也应鼓励各个学科提升自己的学术 能力, 创新经营管理理论和模式, 获得有价值的学术成果。鼓励和资助教师进行成果转化, 将自己的研究结论转化为专利, 转化为切实指导学生开展创业项目的理论源泉, 以此激励教 师不断提高学术能力。在校园里形成自由的学术之风, 商科院校并非满布铜臭之地, 而是回 荡着理论探索之风气，此商是“儒商”。 


\section{3 培养一流企业经营管理者}

对商科高校而言，一流学生就是高素质的企业经营管理者。我国经济改革正处于“深水区”, 亟待商科院校培养出大批具有创新精神和实践能力的杰出企业经营管理者。这些学生学的是 经商，但并非只知“钻钱眼儿”，而是有中国特色的“儒商”，既有国际视野，学习和掌握国际 先进理论，参与国际经济事务，又懂得国内经济现状，适合我国国情。

要培养出素质全面, 特别富于创新精神和实践能力的人才, 需要树立“以学生为中心”的教 育理念, 充分发挥学生的主观能动性。学科课程应该“少而精”, 突出课程的专业化, 按照人 才培养目标和规格, 按照学生成长所需有所依据的开设课程。课程应根据商科高校学生的培 养目标而专门开设, 例如教育经济与管理学科, 应该对教育史有所涉猎, 但一定不可以是直 接把教育学原理专业学生学的那种中外教育史原封不动搬来, 而可以重组为《中外教育史中 的经济思想》, 诸如此类。教学方法以学生学习之所需为转移, 使学生成为学的主体, 让学 生在课堂上动起来。

\section{5. 结 论}

第一，普通地方商科高校要以“双一流”建设为契机，深化学科建设改革，服务区域经济发 展; 第二, 普通地方商科高校一流学科建设可以从三个方面着手：组建一流学术梯队; 获得 一流学术成果，解决经济发展中的新问题；培养一流企业经营管理者。

\section{致谢}

基金项目：黑龙江省教育科学 “十三五” 规划课题（GJD1316011）; 哈尔滨商业大学 2016 年度教学改革与教学研究项目 (HSDJY10(Z) ) ; 2017 年度黑龙江省教育科学规划课题 （GBD1317034）；哈尔滨商业大学博士科研启动项目（14rw11）。

\section{[参 考 文 献]}

[1]田国强.“双一流”建设与经济学发展的中国贡献[J].财经研究,2016,(10):35-49.

[2]周光礼，武建金金.什么是世界一流学科[J].中国高教研究,2016,(1):65-73.

[3]赵蓉英,郭风娇.中国一流学科发展之质量[J].高教发展与评估,2016,(5):1-10.

[4]杨兴林.关于“双一流”建设的三个重要问题思考[J].江苏高教,2016,(2):40-43.

[5] 国务院. 统筹推进世界一流大学和一流学科建设总体方案 [OB/OL]. http://www.gov.cn/zhengce/content/2015-11/05/content_10269.htm.

作者简介:

第一作者: 吴迪 (1984-), 女, 黑龙江哈尔滨人, 讲师, 教育学博士, 主要研究方向为教 育学原理、教育哲学。Email:wdjy1984@126.com

*通讯作者: 刘志国 (1964-), 男, 黑龙江哈尔滨人, 副主任, 副教授, 硕士生导师, 主 要研究方向为高等教育管理。Email:gjpgzx@163.com 